$$
\begin{array}{l|l|l}
\text { Jurnal Eksplorasi Akuntansi } & \text { ISSN : 2656-3649 (Online) } \\
\text { Vol. 2, No 1, Seri D, Februari 2020, Hal 2391-2406 } & \text { http://jea.ppj.unp.ac.id/index.php/jea/issue/view/20 }
\end{array}
$$

\title{
PENGARUH RASIO LIKUIDITAS, SOLVABILITAS, DAN RENTABILITAS TERHADAP RETURN SAHAM PADA PERUSAHAAN LQ45 YANG TERDAFTAR DI BEI PERIODE 2014-2018
}

\author{
Avina Putri Adam', Mayar Afriyenti² \\ ${ }^{1}$ Alumni Jurusan Akuntansi Fakultas Ekonomi Universitas Negeri Padang \\ ${ }^{2}$ Jurusan Akuntansi Fakultas Ekonomi Universitas Negeri Padang \\ *Korespondensi:avinaputriadam@gmail.com
}

\begin{abstract}
This study aims to analyze 1) Does the liquidity ratio affect stock returns on LQ45 companies listed on the Indonesia Stock Exchange Period 2014-2018, 2) does the solvency ratio affect the stock returns on LQ45 companies listed on the Indonesia Stock Exchange 2014-2018 Period, 3) Does the profitability ratio affect the company in returning shares to LQ45 companies listed on the Indonesia Stock Exchange. Causality design was used in this study. Secondary data used by the author is sourced from financial statement data, publication date, LQ45 companies listed on the Indonesia Stock Exchange in the 2014-2018 period were obtained from the website www.idx.co.id. Based on the results of the study found Liquidity ratios have no effect on Return, Solvency Ratios have no effect on Stock Returns, Profitability Ratios have no effect on Stock Returns and together Liquidity Ratios, Solvency Ratios and Profitability Ratios have a significant effect On Stock Returns.
\end{abstract}

Keywords: Liquidity Ratios, Solvency Ratios and Profitability ratios and Stock Return Ratios.

How to Cite (APA $6^{\text {th }}$ style):

Adam, AP \& Afriyenti, Mayar. (2020). Pengaruh Rasio Likuiditas, Solvabilitas, dan Rentabilitas terhadap Return Saham pada Perusahaan LQ45 yang Terdaftar di BEI Periode 20142018. Jurnal Eksplorasi Akuntansi, 2(1), Seri D, 2391-2406.

\section{PENDAHULUAN}

Perusahaan di era ekonomi seperti saat ini sangat membutuhkan modal untuk mendorong kinerja perusahaan operasional. Perusahaan mempunyai cara untuk mendapatkan tambahan modalnya dengan cara menawarkan kepemilikan perusahaan tersebut kepada masyarakat/publik (Go Public). Pasar modal ialah tempat bagi perusahaan untuk mengumpulkan modalnya dengan cara menawarkan modalnya kepada masyarakat/publik. Keterlibtan masyarakat pasar dalam modal dengn cara membeli yang ditawarkan saham oleh pasar modal, baru dikatakan dapat transaksi jual beli terjadi dalam pasar modal sama haknya dengan transaksi yang biasa terjadi di pasar barang atau pasar jasa . 
Pasar modal itu terbagi atas beberapa fungsi yaitu fungsi ekonomi dan fungsi keuangan. Fungsi ekonomi pasar modal dengan menyediakan fasilitas yang memindahkan dana kepada pihak lain dari pihak yang memiliki kelebihan dana kepada pihak yang membutuhkan dana,sedangkan fungsi keuangan pasar modal dengan menyediakan dana yang dibutuhkan oleh pihak lain tanpa harus terlibat secara langsung dalam kegiatan operasional perusahaan (Firdaus,2015).

Investor dan emiten (yang membutuhkan dana) memiliki perbedaan kepentingan dalam aktivitas pasar modalnya. Bagi emiten, cara lain untuk mendapatkan tambahan dana harus tanpa menunggu hasil dari kegiatan operasional disebut pasar modal, sedangkan bagi investor alternatif lain untuk mendapatkan tambahan dana dengan melakukan investasi dan mendapatkan keuntungan yang optimal. Investasi tentunya memiliki risiko, diantaranya yaitu risiko suku bunga, risiko pasar,risiko inflasi, risiko likuiditas, risiko vasa, risiko negara, risiko investment dan nilai tukar mata uang. Investor yang melakukan investasi tidak dapat secara pasti mengetahui risiko apa yang akan diterimanya, dengan itu investor haruslah memimalkan risikonya dan memerlukan analisis untuk menginvestasikan dananya.

Seorang investor mendapatkan return pasti memiliki tujuan utamanya. Return yang diterima oleh pemegang saham perusahaan selalu mengalami fluktuasi dari tahun ketahun, sehingga investor membutuhkan mengenai informasi perusahaan dari laporan keuangannya. Laporan keuangan yang diterbiitkan oleh perusahaan dapat memberikan informasi mengenai kinerja perusahaan tersebut, kemudian dapat dianalisis dengan rasio keuangan yang terdapat dalam laporan keuangan tersebut (Firdaus, 2015).

Laporan keuangan menggambartkan posisi keuangan perusahaan, dalam menilai perusahaan menggunakan rasio-rasio keuangan. Analisis laporan keuangan untuk bertujuan mengetahui kinerja perusahaan yang diukur dengan menggunakan metode analisis rasio. Metode analisis rasio adalah metode yang menentukan hubungan dan mengukur antara pos satu dengan pos yang lainnya yang ada didalam laporan keuangan sehingga dapat mengetahui perubahan dari masing-masing pos tersebut. Metode analisa mengetahui hubungan dari pos-pos tertentu dalam neraca atau laba rugi secara individu kombinasi dari kedua laporan keuangan disebut analisis rasio.

Analisis rasio keuangan berdasarkan definisi tersebut ialah suatu metode analisa yang membandingkan pos laporan keuangan dengan pos lainnya untuk menilai seberapa besar kinerja perusahaan tersebut. Melakukan analisis rasio harusnlah digunakan beberapa rasio diantaranya ada rasio likuiditas, rasio solvabilitas, rasio profitabilitas/rentabilitas, rasio aktivitas, dan rasio pasar, namun dalam penelitian ini openulis hanya mengambil 3 rasio saja yaitu rasio likuiditas, rasio solvabilitas, dan rasio rentabilitas. Alasan penulis menggunakan 3 rasio tersebut adalah 3 rasio ini sudah menjawab dan menggambarkan kinerja sebuah perusahaan (Syofyan, 2013).

Rasio likuiditas merupakan gambaran kemampuan untuk perusahaan menyelesaikan kewajiban jangka pendeknya. Rasio ini terdiri dari current ratio, acid test ratio, dan cash ratio. Pada penelitian ini hanya menggunakan current ratio. Rasio solvabilitas ialah rasio yang mengukur seberapa besar perusahaan berhutang dan ekuitas tersebut. Pada penelitian ini penulis menggunakan debt to equity ratio yang menunjukkan perbandingan antara total hutang dengan modal sendiri. Rasio rentabilitas adalah kemampuan manajemen perusahaan memperoleh labanya yang dengan penjualan, total aktiva, maupun modal sendiri (Syofyan, 2013). Investor yang jangka panjang berinvestasinya akan sangat penting dalam menganalisa profitabilitas ini, misalnya bagi pemegang saham melihat keuntungan yangbenar-benar akan diterimanya dalam 
bentuk dividen. Penulis hanya menggunakan rasio return on equity karena rasio ini digunakan untuk mengukur perusahaan dalam kemampuannya untuk memperolah laba yang dilakukan oleh pemegang saham. Rasio ini merupakan ukuran profitabilitas dari sudut pandang pemegang saham, tetapi tidak memperhitungkan deviden ataupun capital gain (Erich, 2015).

Seorang investor akan menginvestasikan uangnya apabila kondisi perusahaan dalam keuangannya tersebut bagus. Investor yang akan berinvestasi di pasar modal haruslah memilih berinvestasi dalam bentuk sekuritas saham yang berarti berinvestasi dalam prospek perusahaan tersebut. Jenis sekuritas yang paling sangat populer di pasar modal ialah sekuritas saham. Saham ialah surat berharga sebagai bukti penyertaan individu atau institusi atau kepemilikan dalam perusahaan (Erich, 2015). Perusahaan yang bergabung dalam pasar modal harus mampu meningkatkan nilai perusahaanya karena nilai perusahaan yang tinggi tentu memberikan gambaran yang baikdan peluang return yang besar. Perusahaan menganggap semua investor ialah investor yang rasional maka dengan return ekspektasi yang tinggi tentusaja akan semakin banyak yang akan tertarik untuk membeli saham sekuritas seperti investor yang dikeluarkan oleh perusahaan emiten sehingga tujuan pendanaan yang diinginkan perusahaan dan keinginan pasar modal juga terpenuhi.

Indek LQ45 ialah salah satu indek yang diharapkan mempunyai prospek cerah dimasa yang akan datang karena semakin pesatnya pertumbuhan penduduk dan perkembangan di indonesia dalam segi ekonomi yang menjadikan berbagai sektor perusahaan berusaha bersusah payah untuk mendapatkan keuntungan yang tinggi dalam berinvestasi (Suryana, 2017). Indek LQ45 ialah indek likuiditas empat puluh lima buah perusahaan yang selama ini dianggap memiliki kinerja yang dapat dipertanggungjawabkan serta memenuhi kriteria sesuai yang dipersyaratkan oleh manajemen ILQ45 . Berdasarkan Indonesian Capital Market Directory (ICMD). IndeksLQ45 merupakan indikator indeks saham di Bursa Efek Indonesia (BEI) yang merupakan 45 emitten yang dipilih beberapa kriterianya yaitu likuiditas pasar serta menerbitkan saham yang termasuk dalam kategori saham bluechip. Menarik indeks ini hanya 45 saham yang terpilih melalui beberapa kriteria pemilihan dari saham-saham dengan likuiditas tinggi.

Saham perusahaan yang terbaik diseleksi dengan kriteria tertentu yang sudah dicatat pada indeks ini. Bursa Efek Indonesia meninjau ulang kriteria tersebut sekali enam bulan. Apabila pada peninjauan tersebut terdapat saham yang tidak memenuhi kriteria maka saham tersebut akan dikeluarkan dari perhitungan Indeks LQ45 dan akan digantikan dengan perusahaan yang sahamnya memenuhi kriteria tersebut. Indeks LQ45 ialah saham dari emitten yang paling banyak diminati oleh para investor, Indeks LQ45 dijadikan acuan dalam menilai aktivitas kinerja perdagangan saham pasar modal (Susilowati, 2012).

Setiap sekuritas pada dasarnya memiliki nilai return yang berbeda-beda satu sama lainnya. Tidak semua sekuritas akan memberikan return saham yang sama kepada para investor. Suatu sekuritas juga ditentukan oleh banyaknya hal seperti kinerja perusahaan dan strategi perusahaan dalam mengelola labayang dimiliki disebut return. Perusahaan akan dianggap gagal keuangannya apabila perusahaan tersebut tidak mampu membayar kewajibannya pada saat waktu jatuh tempo. Kondisi ini pasti akan membuat investor dan kreditor merasa khawatir jika perusahaan mengalami kesulitan keuangan (Financial Distress) yang langsung mengarah kepada kebangkrutan. Perusahaan yang tidak mampu menghasilkan return yang menguntungkan untuk para investornnya dan pada akhirnya harga sahamnya akan mengalami penurunan apabila perusahaan tersebut diindikasikan gagal keuangannya (Prawira,2016). 
Berikut disajikan perkembangan nilai return saham pada Perusahaan LQ45 yang terdaftar di Bursa Efek Indonesia Periode 2014-2018:

\begin{tabular}{|c|c|c|c|c|c|c|}
\hline Tahun & $\begin{array}{c}\text { Kode } \\
\text { Saham }\end{array}$ & Nama Perusahaan & $\begin{array}{l}\text { Return } \\
\text { Saham }\end{array}$ & $\begin{array}{c}\text { Current } \\
\text { Ratio }\end{array}$ & DER & ROE \\
\hline 2014 & ASII & Astra International Tbk. & 7,425 & 1.32 & 0.96 & 0.18 \\
\hline 2014 & CPIN & Charoen Pokphand Indonesia Tbk. & 3,780 & 2.24 & 0.89 & 0.16 \\
\hline 2014 & GGRM & Gudang Garam Tbk. & 60,700 & 1.62 & 0.75 & 0.16 \\
\hline 2014 & ICBP & Indofood CBP Sukses Makmur Tbk. & 13,100 & 2.19 & 0.72 & 0.18 \\
\hline 2014 & INDF & Indofood Sukses Makmur Tbk. & 6,750 & 1.81 & 1.14 & 0.13 \\
\hline 2014 & INTP & Indocement Tunggal Prakasa Tbk. & 25,000 & 4.93 & 0.18 & 0.22 \\
\hline 2014 & KLBF & Kalbe Farma Tbk. & 1,830 & 3.40 & 0.27 & 0.22 \\
\hline 2014 & SMGR & Semen Indonesia (Persero) Tbk. & 16,200 & 2.18 & 0.37 & 0.22 \\
\hline 2014 & UNVR & Unilever Indonesia Tbk. & 32,300 & 0.71 & 2.11 & 1.25 \\
\hline 2015 & ASII & Astra International Tbk. & 6,000 & 1.38 & 0.94 & 0.12 \\
\hline 2015 & CPIN & Charoen Pokphand Indonesia Tbk. & 2,600 & 2.11 & 0.97 & 0.15 \\
\hline 2015 & GGRM & Gudang Garam Tbk. & 55,000 & 1.77 & 0.67 & 0.17 \\
\hline 2015 & ICBP & Indofood CBP Sukses Makmur Tbk. & 6,738 & 2.33 & 0.62 & 0.18 \\
\hline 2015 & INDF & Indofood Sukses Makmur Tbk. & 5,175 & 1.71 & 1.13 & 0.09 \\
\hline 2015 & INTP & Indocement Tunggal Prakasa Tbk. & 22,325 & 4.89 & 0.16 & 0.18 \\
\hline 2015 & KLBF & Kalbe Farma Tbk. & 1,320 & 3.70 & 0.25 & 0.19 \\
\hline 2015 & SMGR & Semen Indonesia (Persero) Tbk. & 11,400 & 1.60 & 0.39 & 0.16 \\
\hline 2015 & UNVR & Unilever Indonesia Tbk. & 37,000 & 0.65 & 2.26 & 1.21 \\
\hline 2016 & ASII & Astra International Tbk. & 8,275 & 1.24 & 0.87 & 0.13 \\
\hline 2016 & CPIN & Charoen Pokphand Indonesia Tbk. & 3,090 & 2.13 & 0.71 & 0.16 \\
\hline 2016 & GGRM & Gudang Garam Tbk. & 63,900 & 1.94 & 0.59 & 0.17 \\
\hline 2016 & ICBP & Indofood CBP Sukses Makmur Tbk. & 8,575 & 2.41 & 0.56 & 0.20 \\
\hline 2016 & INDF & Indofood Sukses Makmur Tbk. & 7,925 & 1.51 & 0.87 & 0.12 \\
\hline 2016 & INTP & Indocement Tunggal Prakasa Tbk. & 15,400 & 4.53 & 0.15 & 0.15 \\
\hline 2016 & KLBF & Kalbe Farma Tbk. & 1,515 & 4.13 & 0.22 & 0.19 \\
\hline 2016 & SMGR & Semen Indonesia (Persero) Tbk. & 9,175 & 1.27 & 0.45 & 0.15 \\
\hline 2016 & UNVR & Unilever Indonesia Tbk. & 38,800 & 0.61 & 2.56 & 1.36 \\
\hline 2017 & ASII & Astra International Tbk. & 7,850 & 1.23 & 0.89 & 0.15 \\
\hline
\end{tabular}




\begin{tabular}{lllcccc}
\hline 2017 & CPIN & Charoen Pokphand Indonesia Tbk. & 3,000 & 2.32 & 0.56 & 0.16 \\
\hline 2017 & GGRM & Gudang Garam Tbk. & 66,125 & 19.36 & 0.58 & 0.18 \\
\hline 2017 & ICBP & Indofood CBP Sukses Makmur Tbk. & 9,100 & 2.43 & 0.56 & 0.17 \\
\hline 2017 & INDF & Indofood Sukses Makmur Tbk. & 6,270 & 1.50 & 0.88 & 0.11 \\
\hline 2017 & INTP & Indocement Tunggal Prakasa Tbk. & 17,000 & 3.70 & 0.18 & 0.08 \\
\hline 2017 & KLBF & Kalbe Farma Tbk. & 1,495 & 4.51 & 0.20 & 0.18 \\
\hline 2017 & SMGR & Semen Indonesia (Persero) Tbk. & 13,725 & 1.57 & 0.63 & 0.05 \\
\hline 2017 & UNVR & Unilever Indonesia Tbk. & 49,400 & 0.63 & 2.65 & 1.35 \\
\hline 2018 & ASII & Astra International Tbk. & 6,850 & 1.15 & 0.98 & 0.16 \\
\hline 2018 & CPIN & Charoen Pokphand Indonesia Tbk. & 4,200 & 2.98 & 0.43 & 0.23 \\
\hline 2018 & GGRM & Gudang Garam Tbk. & 68,825 & 2.06 & 0.53 & 0.17 \\
\hline 2018 & ICBP & Indofood CBP Sukses Makmur Tbk. & 10,100 & 1.95 & 0.51 & 0.21 \\
\hline 2018 & INDF & Indofood Sukses Makmur Tbk. & 6,270 & 1.07 & 0.93 & 0.10 \\
\hline 2018 & INTP & Indocement Tunggal Prakasa Tbk. & 18,000 & 3.14 & 0.20 & 0.05 \\
\hline 2018 & KLBF & Kalbe Farma Tbk. & 1,115 & 4.66 & 0.19 & 0.16 \\
\hline 2018 & SMGR & Semen Indonesia (Persero) Tbk. & 14,725 & 1.95 & 0.56 & 0.09 \\
\hline 2018 & UNVR & Unilever Indonesia Tbk. & 52,400 & 0.75 & 1.58 & 1.20 \\
\hline & & & & & & \\
\hline
\end{tabular}

Berdasarkan data diatas dapat disimpulkan bahwa terdapat fluktuasi nilai return saham, Current Ratio, DER, dan ROE masing-masing perusahaan LQ45 yang terdaftar di Bursa Efek Indonesia Periode 2014-2018. Angka masingmasing indikator mengalami fluktuatif setiap tahunnya pada masingmasing perusahaan. Uraian latar belakang di atas dan masalah yang ditemukan kondisi return saham pada perusahaan LQ45 selama 5 tahun terakhir yang berfluktuatif maka penulis tertarik untuk melakukan penelitian lebih lanjut mengenai penilaian kinerja perusahaan dengan menggunakan analisis rasio dengan judul "Pengaruh Rasio Likuiditas, Solvabilitas, Dan Rentabilitas Terhadap Return Saham Pada Perusahaan Lq45 Yang Terdaftar Di Bursa Efek Indonesia Periode 2014-2018”.

\section{REVIU LITERATUR DAN PENGEMBANGAN HIPOTESIS Teori Keagenan}

Teori keagenan dapat terjadi antara dua pihak yang melakukan kesepakatan yaitu hubungan yang muncul satu pihak ketika (principal) memberikan/mendelegasikan kewenanganya dan tanggung jawab kepada pihak lain (agent) ysng melakukan pengambilan keputusan. Lupia \& McCubbins (2000) dalam Wau \& Ratmono (2015) menyatakan bahwa pendelegasian bakal terjadi antara kelompok orang menunjuk orang lain atau kelompok lain menujuk seseorang atau untuk bertidak sesuai dengan kepentingan prinsipalnya, hal ini dapat dilihat juga dalam sistem pemerintahan di Indonesia. 
Hubungan antara masyarakat/pemilih dengan pimpinan dari pemerintahan/politikus dapat disebut sebagai hubungan agensi. Pada pemerintahan di Indonesia, pemerintah daerah bertindak sebagai agent yang menyelenggarakan urusan pemerintahan sesuai kepentingan masyarakat selaku principal. Masyarakat sebagai principal harus memberikan amanat kepada pemerintah daerahnya untuk dapat menjalankan kegiatan di pemerintahan. Pemerintah daerah sebagai agent haruslah mempunyai kewajiban dan harus melaporkan hasilnya dalam pelaksanaan pemerintahan kepada masyarakat. Hasil pelaksanaan pemerintahan harus terkait dengan penggunaan sumber daya yang telah dipercayakan masyarakat sebagai prinsipal adalah dalam bentuk laporan keuangan.

\section{Return Saham}

Salah satu fatkor yang mendorong investor untuk berinvestasi dan merupakan imbalan atas keberanian para investor menanggung risiko yang diterimanya atas investasi yang dilakukannya disebut return saham. Penghasilan yang diperoleh selama investasi per periode sejumlah dana yang akan diinvestasikan bentuk dalam saham dimaksud Return saham. Kinerja keuangan yang secara langsung mempengaruhi return saham yang dikelompokkan ke beberapa rasio yaitu rsio likuiditas, rasio solvabilitas, rasio profitabilitas/rentabilitas, rasio aktivitas, rasio pasar, dan Economic Value Added (EVA). (Asnawi dan Wjiaya, 2015:95).

1. Perusahaan mampu dalam memenuhi kewajiban jangka pendek disebut rasio likuiditas

2. Perusahaan mampu dalam memenuhi kewajiban jangka panjang disebut rasio solvabilitas

3. Perusahaan mampu dalam memanfaatkan harta yang dimilikinya disebut rasio aktivitas

4. Perusahaan mampu dalam menghasilkan keuntungan disebut rasio rentabilitas /profitabilitas

5. Informasi yang penting bagi perusahaan dan diungkapkan dalam basis per saham disebut rasio pasar

6. EVA yaitu suatu cara untuk mengukur profitabilitas operasional sesungguhnya, apakah perusahaan sudah mampu memberikan nilai tambahnya atau belum untuk perusahaan. Manajemen kinerja untuk meningkatkan harga saham perusahaan haruslah baik atau efektif yang akan dilihat dari segi nilai tambahnya. EVA yang positif akan meningkatkan harga saham perusahaan, begitu juga untuk profitabilitas, jika meningkat akan mendapatkan harga saham juga.

\section{Laporan Keuangan}

Laporan keuangan ialah laporan yang berisi informasi keuangan sebuah perusahaan atau organisasi. Sarana mengkomunikasikan informasi keuangan terutama kepada pihak eksternal akan diterbitkan oleh perusahaan yang merupakan hasil dari proses akuntansi yang dimaksudkan sebagai laporan keuangan. PSAK No.1 Paragraf ke 7 (revisi 2012), menyatakan " Laporan keuangan adalah posisi keuangan dan kinerja dari suatu entitas yang akan disaji secara terstruktur".

\section{Rasio Likuiditas}

Rasio likuiditas ialah apakah perusahaan mampu memenuhi kewajiban jangka pendeknya. Rasiorasio ini dapat dihitung melalui sumber informasi tentang modal kerja yaitu aktiva lancar dengan hutang lancar. 


\section{Rasio Solvabilitas}

Apakah perusahaan mampu dalam memnuhi kewajiban jangka panjangnya. Beberapa cara yang bisa digunakan untuk menilai rasio ini:

a. Membiayai sejumlah aktiva yang dimilikinya ialah salah satu Cara perusahaan.

b. Modal pemilik (seperti bunga obligasi pinjaman) berasal dari apakah perusahaan mampu dalam membayar beban tetap disebabkan pemakaian sumber pembiayaan

\section{Rasio Rentabilitas / Profitabilitas}

Rasio ini menunjukkan apakah manajemen perusahaan mampu dalam memperoleh labanya yang berhubungan dengan penjualan, total aktiva, maupun modal sendiri. Analisa profitabilitas jangka panjang ini bagi investor akan sangat penting, misalnya bagi pemegang saham untuk dapat melihat keuntungan yang benar-benar akan diterima dalam bentuk deviden.

\section{Pengaruh Rasio Likuiditas terhadap Return Saham pada Perusahaan LQ45}

Rasio likuiditas memperlihatkan semakin tinggi likuiditas suatu perusahaan, maka semakin besar pula kemampuan suatu perusahaan dalam memenuhi kewajiban jangka pendeknya yang nantinya akan meningkatkan kepercayaan investor dan kreditur pada perusahaan, sehingga sumber dana jangka pendek haruslah dapat terpenuhi dan return saham juga dapat ditingkatkan. Unexpected cash inflows atau outflows dari periode operasi tertentu akan mempengaruhi harga saham dengan cara mempengaruhinya pada arus kas, sehingga diharapkan komponen arus kas dari operasi ada berhubungan signifikan dengan return saham (Wingsih, 2013).

Peran variabel likuiditas ialah memiliki pengaruh yang positif dan signifikan terhadap return saham pada periode ke depan. Dikatakan, likuiditas berpengaruh terhadap return saham, semakin besar rasio ini maka semakin baik perusahaan dalam menjaga keseimbangan operasionalnya sehari-hari. Pemodal akan memperoleh return yang lebih tinggi jika kemampuan perusahaan tersebut memenuhi kewajiban jangkapendeknya yang semakin tinggi.

H1: Rasio likuiditas berpengaruh negatif terhadap return saham pada perusahaan LQ45 yang Terdaftar di Bursa Efek Indonesia Periode 2014-2018.

\section{Pengaruh Rasio Solvabilitas terhadap Return saham pada Perusahaan LQ45}

Rasio solvabilitas perusahaan menggambarkan kemampuan suatu perusahaan untuk memenuhi kewajiban jangka panjangnya. Debt to Equity Ratio (DER) ialah rasio solvabilitas yang digunakan untuk mengukur sebarapa besar modal yang mampu dikumpulkan oleh investor atau perusahaan untuk digunakan sebagai jaminan segala macam hutang perusahaan. Rasio solvabilitas jika rendah maka yang berhubungan dengan perusahaan pasti akan mempunyai resiko ketika kerugian perusahaan lebih kecil dari keadaan ekonominya yang merosot, dan ketika kondisi ekonomi perusahaan naik atau membaik, maka ini kesempatan pula bagi perusahaan untuk memperoleh laba rendah. Sedangkan, perusahaan dengan rasio leverage yang tinggi, maka akan beresiko menanggung semua kerugian yang besar ketika keadaan ekonomi perusahaan tersebut merosot, tetapi mempunyai kesempatan untuk memperoleh laba lebih besar saat kondisi ekonomi perusahaan membaik.

Debt to Equity Ratio memberikan pengaruh yang positif bagi return saham, semakin tinggi DER maka akan menunjukkan komposisi total hutang suatu perusahaan dengan modalnya sendiri, sehingga dampaknya akan semakin besar beban perusahaan tersebut terhadap pihak luar (kreditor). Meningkatnya suatu beban terhadap kreditor maka akan menunjukkan total sumber 
modal perusahaan bergantung sangat dengan pihak luar, karena itu juga dapat mengurangi minat investor untuk menanamkan dananya ke perusahaan tersebut karena return saham yang semakin menurun"

H2: Rasio solvabilitas berpengaruh negatif terhadap return saham pada Perusahaan LQ45 yang Terdaftar di Bursa Efek Indonesia Periode 2014-2018.

\section{Pengaruh Rasio Rentabilitas terhadap Return saham pada Perusahaan LQ45}

Setiap perusahaan pasti mempunyai tujuan akhir yang ingin dicapainya suatu saat nanti. Salah satunya perusahaan yaitu untuk memperoleh keuntungan yang maksimal. Keuntungan yang maksimal tersebut akan digunakan bagi kesejahteraan pemilik, karyawan, serta untuk meningkatkan produk mutudan melakukan investasi baru. Perusahaan dalam segi manajemen wajib harus dituntut mampu/bisa untuk memenuhi atau mencapai target yang telah ditetapkan sebelumnya, seberapa besar keuntungan haruslah dicapai sesuai dengan yang telah diharapkan waktu itu. Rentabilitas menggambarkan rasio yang untuk menilai digunakan apakah perusahaan mampu dalam mencari keuntungannya.

Rentabilitas diukur dengan Return On Equity (ROE). Semakin tinggi ROE berarti semakin baik perusahaan dalam kinerjanya dalam mengelola modalnya untuk menghasilkan keuntungan (return) bagi para pemegang saham secara dan efisien efektif untuk memperoleh laba. ROE digunakan untuk mengukur seberapa besar pemegang sahamdapat pengembalian terhadap investasinta. Angka tersebut akan menunjukkan seberapa baik manajemen dalam memanfaatkan investasi para pemegang saham. Semakin besarROE semakin besar pula return saham, karena besarnya ROE memberikan indikasi bahwa pengembalian yang akanditerima investor akan tinggi, hal ini menyebabkan return saham cenderung naik."

H3: Rasio rentabilitas berpengaruh negatif terhadap return saham pada Perusahaan LQ45 yang Terdaftar di Bursa Efek Indonesia Periode 2014-2018.

\section{Kerangka Konseptual}

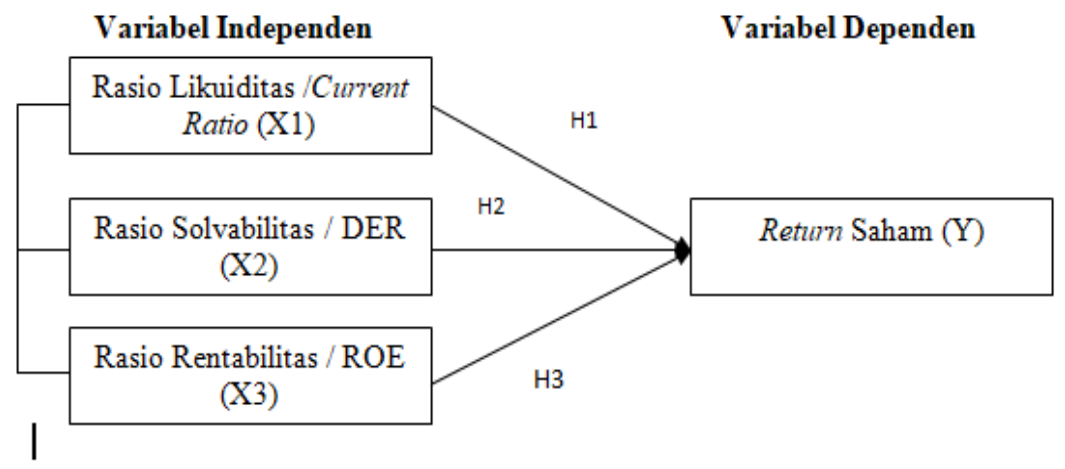

\section{Gambar 1. Kerangka Konseptual}

\section{METODE PENELITIAN}

\section{Jenis Penelitian}

Desain yang akan digunakan dalam penelitian ini ialah desain kausalitas yang merupakan Desain penelitian yang berfungsi untuk bisa melihat hubungan-hubungan yang ada antara satu 
dari variabel dengan variabel lainya. Sifat tersebut dari hubungan-hubungan yang mungkin dapat terjadi diantara variabel-variabel tersebut merupakan asimetris, simetris serta juga timbal balik.

\section{Populasi dan Sampel}

Populasi dapat diartikan sebagai suatu tempat maupun wilayah bergeneralisasi yang terdapat pada objek ataupun subjek yang memiliki kualitas dan jenis tertentu. Maka selain itu sampel diartikan sebagian dari keseluruhan serta karakteristik yang diperoleh oleh populasi diwilayah tersebut. Populasi ialah keseluruhan jumlah atau himpunan dari obyek yang juga sama dan populasi sebenarnya berasal dari kata bahasa inggris yaitu dari kata population, yang memilki arti jumlah dari penduduk. Dalam metodologi penelitian, kata dari populasi juga dapat disebut sangat amat popular karena dipakai untuk menyebutkan kata serumpun atau sekelompok objek yang dapat dijadikan menjadi sebuah sasaran yang ada pada penelitian. Pada penjelasan yang disebut para ahli sebelumnya, dapat dikatakan bahwa bentuk dari populasi yang dipakai pada penelitian ini ialah perusahaan yang termasuk pada kategori yang kemudian menjadi Indeks pada LQ45. Indeks pada LQ45 dapat disebut sebagai salah satu dari indeks yang ada pada di Bursa Efek Indonesia (BEI).

Sampling dapat dikatakan juga sebagai proses dalam memilih pada sejumlah elemen yang secukupnya dari dalam populasi terseut. Sementara menurut penjelasan Agussalim (2010:98) sampel daapat disebut sebagai himpunan yang ada dari bagian atau juga dari sebagian populasi. Metode sampel yang akan peneliti pakai adalah metode pada puposseive sampling. Purposive sampling dapat diartikan sebagai teknik dari sebuah penentuan sampel dengan memakai beberapa dari pertimbangan tertentu. Adapun kriteria serta juga pertimbangan yang akan dipakai oleh peneliti adalah:

1. Tercatat sebagai perusahaan dalam manufaktur yang ada pada tahun 2018 digunakan sebanyak 45 perusahaan.

2. Yang tidak tercatat berturut-turut yang merupakan juga termasuk bagian dari anggota pada Indeks LQ45 yang ada sejak tahun tercatat di tahun 2014 yaitu merupakan setidaknya 36 perusahaan.

3. Yang berturut-turut menjadi anggota Indeks LQ45 sejak tahun 2014 sebanyak 9 perusahaan.

\section{Jenis, Sumber Data dan Teknik Pengumpulan Data}

Jenis data yang akan dipakai ialah jenis data dari kuantitatif, yakni merupakan angka yang kemudian disusun dan diurutkan dalam bentuk data. Data dari kuantitatif yang ada pada penelitian ini merupakan sumber dari Laporan Keuangan diperusahaan yang LQ45 yang telah tercata didalam Bursa Efek Indonesia. Teknik yang akan dilakukan dalam pengumpulan pada data yang penulis pakai dalam sebuah penelitian disini adalah dokumentasi. Penulis mengumpulkan data yang juga didapatkan dari bermacam sumber. Antara lain data dari laporan keuangan tahunan yang ada pada perusahaan di LQ45 yang kemudian telah terdaftar dibagian Bursa Efek Indonesia Periode pada tahun 2014-2018 melalui media website yang resmi pada IDX (www.idx.co.id), serta juga jurnal dan bacaan yang digunakan sebagai bagian dari referensi.

Sumber data yang dipakai oleh penulis pakai didalam penelitian disini adalah penelitian pada data sekunder, yaitu sumber yang terdapat pada penelitian yang kemungkin didapatkan secara bentuk tidak langsung yang dipakai melalui adanya media yang berfungsi sebagai perantara. Sehingga suatu dalam penelitian yang ada pada data sekunder yang terdapat didalam penelitian ini dapat diperoleh dari: 
1. Data dari laporan keuangan yang pada tanggal adanya publikasi, perusahaan yang termasuk pada LQ45 yang telah tercatat pada Bursa Efek Indonesia Periode tahun 2014-2018 yang kemudian diperoleh dari media website. www.idx.co.id

2. Data dari adanya harga yang terdapat pada Saham harian yang juga didapatkan dari website yakni media www.yahoofinance.com

3. Data yang ada dalam Perusahaan pada manufaktur kemudaian akan didapatkan dari www.sahamok.com

4. Berdasarkan pada sumber lain yang mana apa saja yang peneliti butuhkan untuk melakukan penyelesaikan yang ada dipenelitian ini.

\section{HASIL PENELITIAN DAN PEMBAHASAN Analisis Regresi Linear Berganda}

Analisis pada regresi dari linear berganda dipakai agar untuk dapat melihat jumlah apakah akan adanya pengaruh yang terdapat pada variable yang bebas kepada variabel yang terikat. Variabel bebas sebenarnya akan dipakai juga dalam penelitian disini ialah rasio likuiditas, rasio yang solvabilitas dan rasio rentabilitas selain itu variabel yang terikatnya juga merupakan return saham. Hasil dari analisis yang ada pada SPSS mengenai apa saja Pengaruh dari Rasio Keuangan Terhadap pengaruh dari Return Saham yang ada Pada Perusahaan yang LQ45 Yang sebenarnya Terdaftar Dalam Bursa Efek Indonesia yang mana ada diPeriode tahun 2014-2018 kemudian dapat dilihat melalui pada tabel 4.15. Untuk dapat melihat apa saja Pengaruh dari Rasio Keuangan yang ada Terhadap pengaruh dari Return Saham Pada Perusahaan yang terdapat didalam LQ45 Yang sudah Tercatat Di Bursa Efek Indonesia pada Periode tahun 2014-2018 .

Tabel 1. Hasil Analisis Regresi Linear Berganda

\begin{tabular}{|c|c|c|c|c|c|c|}
\hline \multirow{2}{*}{\multicolumn{2}{|c|}{ Model }} & \multicolumn{2}{|c|}{$\begin{array}{l}\text { Unstandardized } \\
\text { Coefficients }\end{array}$} & \multirow{2}{*}{$\begin{array}{l}\text { Standardized } \\
\text { Coefficients } \\
\text { Beta }\end{array}$} & \multirow[t]{2}{*}{$\mathrm{t}$} & \multirow[t]{2}{*}{ Sig. } \\
\hline & & $\bar{B}$ & Std. Error & & & \\
\hline \multirow[t]{4}{*}{1} & (Constant) & 12.154 & 3.820 & & 3.182 & .003 \\
\hline & CURRENT & -0.416 & .329 & -.174 & -1.265 & .213 \\
\hline & DER & 5.660 & 3.192 & .281 & 1.773 & .084 \\
\hline & ROE & 13.658 & 8.308 & .264 & 1.644 & .108 \\
\hline
\end{tabular}

Sumber: Data Primer Diolah, 2019 (Lampiran 4)

Berdasarkan tabel 1 dapat dibuat persamaan regresi linear berganda sebagai berikut:

$$
Y=12.154+(-0,416) \mathrm{X} 1+5.660 \mathrm{X}+13.658 \mathrm{X} 3+\mathrm{e}
$$

Dari persamaan di atas dapat diinterpretasikan beberapa hal, sebagai berikut:

1. Konstanta sebesar 12.154 , artinya jika tidak ada current ratio, DER dan ROE $(\mathrm{X} 1=\mathrm{X} 2=\mathrm{X} 3=0)$ maka nilai return saham pada Perusahaan LQ45 Yang Terdaftar Di Bursa Efek Indonesia Periode 2014-2018 adalah sebesar konstanta yaitu 12.154 satuan.

2. Koefisien rasio likuiditas adalah sebesar -0.416 artinya rasio likuiditas tidak berpengaruh terhadap return saham dimana jika rasio likuiditas dinaikan satu satuan maka return saham akan naik sebesar -0.416 satuan. 
3. Koefisien rasio solvabilitas adalah sebesar 5.660 artinya rasio solvabilitas tidak berpengaruh terhadap return saham dimana jika rasio solvabilitas dinaikan satu satuan maka return saham akan naik sebesar 5.660 satuan.

4. Koefisien rasio rentabilitas adalah sebesar 13.658 artinya rasio rentablitas tidak berpengaruh terhadap return saham dimana jika rasio rentabilitas dinaikan satu satuan maka return saham akan naik sebesar 13.658 satuan.

\section{Koefisien Determinan}

Koefisien determinasi berguna untuk melihat kontribusi pengaruh variabel bebas terhadap variabel terikat. Untuk mengetahui seberapa besar kontribusi Pengaruh Rasio Keuangan Terhadap Return Saham Pada PerusahaanLQ45 Yang Terdaftar Di Bursa Efek Indonesia Periode 2014-2018dapat dilihat pada tabel 2 :

Tabel 2. Koefisien Determinasi

\begin{tabular}{lllll}
\hline Model & $\mathrm{R}$ & R Square & $\begin{array}{l}\text { Adjusted } \\
\text { Square }\end{array}$ & $\begin{array}{l}\text { R Std. Error of the } \\
\text { Estimate }\end{array}$ \\
\hline 1 & $0.519^{\mathrm{a}}$ & 0.269 & 0.216 & 17.684181 \\
\hline \multicolumn{4}{c}{ Sumber : Hasil Pengolahan Data, 2019 }
\end{tabular}

Berdasarkan tabel 2, nilai koefisien determinasi Return Saham Pada Perusahaan LQ45 yang terdaftar di Bursa Efek Indonesia Periode 2014-2018 ditunjukan dengan nilai Adjust $R$ Square sebesar 0,216, halini berarti besarnya kontribusi terhadap pengaruh rasio likuiditas,rasio solvabilitas dan rasio rentabilitas terhadap Return Saham Pada Perusahaan LQ45 yang terdaftar di Bursa Efek Indonesia Periode 2014-2018 adalah sebesar 0,21,6\%\% sedangkan sisanya dipengaruhi oleh variabel lain seperti acid test ratio, cash ratio, debt ratio dan time interest current ratio.

\section{Pengujian Hipotesis}

Melihat dan menguji dari hipotesis dilihat secara bentuk parsial dari bagian dan juga simultan kemudian dilakukan dalam uji pada statistik t serta pada $\mathrm{f}$.

\section{Uji t}

Melihat pengaruh antara variable dari independen dengan variabel yang dependen. Dengan memakai program dari SPSS V.20 sehingga dapat didapatkan besarnya nilai t yang diukur pada tabel 4.8 sebagai berikut :

Tabel 3. Uji t

\begin{tabular}{|c|c|c|c|c|c|c|}
\hline \multirow{2}{*}{\multicolumn{2}{|c|}{ Model }} & \multicolumn{2}{|c|}{$\begin{array}{l}\text { Unstandardized } \\
\text { Coefficients }\end{array}$} & \multirow{2}{*}{$\begin{array}{l}\text { Standardized } \\
\text { Coefficients } \\
\text { Beta }\end{array}$} & \multirow[t]{2}{*}{$\mathrm{t}$} & \multirow[t]{2}{*}{ Sig. } \\
\hline & & $\mathrm{B}$ & Std. Error & & & \\
\hline \multirow[t]{4}{*}{$\overline{1}$} & (Constant) & 12.154 & 3.820 & & 3.182 & .003 \\
\hline & CURRENT & -0.416 & .329 & -.174 & -1.265 & .213 \\
\hline & $\overline{\text { DER }}$ & 5.660 & 3.192 & .281 & 1.773 & .084 \\
\hline & ROE & 13.658 & 8.308 & 264 & 1.644 & .108 \\
\hline
\end{tabular}

Sumber : Hasil Pengolahan Data, 2019 
Berdasarkan tabel 3 dapat dijelaskan uji t sebagai berikut:

1. Nilai t hitung rasio likuiditas adalah sebesar -1.265 dengan nilai signifikansi sebesar 0,213. Nilai $t$ tabel dengan $\mathrm{df}=45-3=42$ dengan $\alpha=5 \%$ maka diperoleh $\mathrm{t}$ tabel sebesar 1.682. Dari hasil di atas dapat dilihat nilai $t$ hitung $<\mathrm{t}$ tabel dan signifikansi $(0,213>0,05)$, maka dapat disimpulkan bahwa H1 ditolak, bahwa rasio likuiditas tidak berpengaruh signifikan terhadap Return Saham Pada PerusahaanLQ45 Yang Terdaftar Di Bursa Efek Indonesia Periode 2014-2018

2. Nilai t hitung rasio solvabilitas adalah sebesar 1.773 dengan nilai signifikansi sebesar 0,084 . Nilai $\mathrm{t}$ tabel dengan $\mathrm{df}=45-3=42$ dengan $\alpha=5 \%$ maka diperoleh $\mathrm{t}$ tabel sebesar 1.682. Dari hasil di atas dapat dilihat nilai $t$ hitung $<\mathrm{t}$ tabel dan signifikansi $(0,0,084>0,05)$, maka dapat disimpulkan bahwa $\mathrm{H} 2$ ditolak, bahwa rasio solvabilitas tidak berpengaruh signifikan terhadap Return Saham Pada PerusahaanLQ45 Yang Terdaftar Di Bursa Efek Indonesia Periode 2014-2018.

3. Nilai t hitung rasio rentabilitas adalah sebesar 1.644 dengan nilai signifikansi sebesar 0,108 . Nilai t tabel dengan df $=45-3=42$ dengan $\alpha=5 \%$ maka diperoleh t tabel sebesar 1.682. Dari hasil di atas dapat dilihat nilai $t$ hitung $<\mathrm{t}$ tabel dan signifikansi $(0,108>0,05)$, maka dapat disimpulkan bahwa H3 ditolak, bahwa rasio rentabilitas tidak berpengaruh signifikan terhadap Return Saham Pada PerusahaanLQ45 Yang Terdaftar Di Bursa Efek Indonesia Periode 2014-2018

\section{Uji F}

Uji F sebenarnya dipakai untuk agar dapat melihat seberapa besar pengaruh dari semua secara keseluruhan dari yang variabel independen juga terhadap variable yang dependen. Dengan menggunakan bantuan dari program media SPSS V.20 sebab itu pula dapat dilihat seberapa nilai dari F yang dihitung pada table dalam Anova yakni sebagai berikut :

Tabel 4. Uji f

\begin{tabular}{lllllll}
\hline Model & Jumlah & df & Rata-rata & F & Sig. \\
\hline \multirow{3}{*}{1} & Regression & 4725.465 & 3 & 1575.155 & 5.037 & $.005^{\mathrm{b}}$ \\
\cline { 2 - 7 } & Residual & 12821.941 & 41 & 312.730 & & \\
\cline { 2 - 8 } & Total & 17547.406 & 44 & & & \\
\hline
\end{tabular}

Sumber : Hasil Pengolahan Data, 2019

Berdasarkan tabel 4 diketahui bahwa nilai $\mathrm{F}$ hitung 5.037 dengan nilai signifikansi sebesar 0,005 ( $\mathrm{p}>0,05)$. Hal ini berarti bahwa secara bersama-sama rasio likuiditas, rasio solvabilitas dan rasio rentabilitas berpengaruh signifikan terhadap Return Saham Pada PerusahaanLQ45 Yang Terdaftar Di Bursa Efek Indonesia Periode 2014-2018.

\section{Pembahasan}

\section{Pengaruh Rasio Likuiditas terhadap Return Saham}

Hasil penelitian ditemukanNilai t hitung rasio likuiditas adalah sebesar -1.265 dengan nilai signifikansi sebesar 0,213 . Nilai t tabel dengan $\mathrm{df}=45-3=42$ dengan $\alpha=5 \%$ maka diperoleh $\mathrm{t}$ tabel sebesar 1.682. Dari hasil diatas dapat dilihat nilai $\mathrm{t}$ hitung $<\mathrm{t}$ tabel dan signifikansi (0,213>0,05), maka dapat disimpulkan bahwa H1 ditolak, bahwa rasio likuiditas tidak berpengaruh signifikan terhadap Return Saham Pada PerusahaanLQ45 Yang Terdaftar Di 
Bursa Efek Indonesia Periode 2014-2018, Current Ratio menunjukkan apakah perusahaan mampu dalam memenuhi kewajiban hutang jangka pendek dengan aktiva lancar yang tersedia, selain itu CR juga menunjukkan tingkat likuiditas perusahaan.

Ditolaknya hipotesis ini disebabkan oleh masih adanya perusahaan LQ45 Yang Terdaftar diBursa Efek Indonesia Periode 2014-2018 memiliki nilai current ratio dibawah 2, sedangkan menurut Kasmir (2012) standar nilai current ratio sebesar 2. Hasil penelitian ini didukung oleh penelitian yang dilakukan oleh Ulul Nur Azizah (2018) ditemukan Current Ratio tidak berpengaruh signifikan terhadap return saham pada perusahaan manufaktur yang terdaftar di Bursa Efek Indonesia pada tahun 2013-2015. Hal ini ditunjukkan oleh nilai signifikansi sebesar 0,466 lebih besar dari 0,05, sehingga hipotesis ketiga ditolak dan current ratio tidak dapat digunakan untuk memprediksi return saham pada perusahaan manufaktur yang terdaftar di Bursa Efek Indonesia .

Rasio likuiditas yang menyatakan apakah perusahaan mampu untuk menuhi kewajibannya dalam waktu jangka waktu pendek. Rasio ini menggunakan current ratio. Semakin tinggi rasio ini makasemakin baik pula return saham yang akan diterima investor.CR yang rendah biasanya hanya dianggap menunjukkan terjadinya masalah dalam likuidasi, sebaliknya current ratio yang terlalu tinggi juga kurang bagus, karena menunjukkan banyaknya dana yang menganggur pada akhirnya dapat mengurangi kemampulabaan perusahaan (Sawir,2009).

\section{Pengaruh Rasio Solvabilitas terhadap Return Saham}

Hasil penelitian ditemukanNilai $t$ hitung rasio solvabilitas adalah sebesar 1.773 dengan nilai signifikansi sebesar 0,084. Nilai t tabel dengan $\mathrm{df}=45-3=42$ dengan $\alpha=5 \%$ maka diperoleh $\mathrm{t}$ tabel sebesar 1.682. Dari hasil di atas dapat dilihat nilai $\mathrm{t}$ hitung $<\mathrm{t}$ tabel dan signifikansi $(0,0,084>0,05)$, maka dapat disimpulkan bahwa $\mathrm{H} 2$ ditolak, bahwa rasio solvabilitas tidak berpengaruh signifikan terhadap Return Saham Pada PerusahaanLQ45 Yang Terdaftar Di Bursa Efek Indonesia Periode 2014-2018.

Hasil penelitian ini didukung oleh penelitian yang dilakukan oleh Ulul Nur Azizah (2018) ditemukan rasio solvabilitas diwakili oleh Debt to Equity Ratio (DER) tidak berpengaruh signifikan terhadap return saham pada perusahaan manufaktur yang terdaftar di Bursa Efek Indonesia. Hal ini ditunjukkan oleh nilai signifikan sebesar 0,743 yang lebih besar dari 0,05, sehingga hipotesis kedua ditolak dan DER tidak dapat digunakan untuk mempredik return saham pada perusahaan manufaktur yang terdaftar di Bursa Efek Indonesia . Penelitian oleh Farkhan (2013) ditemukan rasio solvabilitas tidak berpengaruh signifikan terhadap Return Saham, tidak adanya pengaruh DER terhaadap return saham dikarenakan sebagian investor menganggap bahwa perusahaan yang memiliki prospek keberanian yang baikuntuk menggunakan hutang dalam yang tinggi tergadap struktur modalnya, maka proporsi hutang yang makin tinggi akan mengakibatkan fixed paymant yang mengakibatkan risiko kebangkrutan pada perusahaan.

Rasio pada solvabilitas, menampilkan seberapa dari kemampuan perusahaan yakni dalam upaya untuk dapat memenuhi salah satu kewajiban dari jangka panjang mana ada rasio ini memakai debt to equity ratio yaitu merupakan saham yang dapat mengurangi betapa besarnya dari pengembalian yang telah diharapkan, maka akan dapat berpotensial juga untuk dapat mengurangi hal dalam penggunaan dari return saham. 


\section{Pengaruh Rasio Rentabilitas terhadap Return Saham}

Hasil penelitian ditemukanNilai t hitung rasio rentabilitas adalah sebesar 1.644 dengan nilai signifikansi sebesar 0,108. Nilai t tabel dengan $\mathrm{df}=45-3=42$ dengan $\alpha=5 \%$ maka diperoleh $\mathrm{t}$ tabel sebesar 1.682. Dari hasil di atas dapat dilihat nilai $\mathrm{t}$ hitung $<\mathrm{t}$ tabel dan signifikansi $(0,108>0,05)$, maka dapat disimpulkan bahwa $\mathrm{H} 3$ ditolak, bahwa rasio rentabilitas tidak berpengaruh signifikan terhadap Return Saham Pada PerusahaanLQ45 Yang Terdaftar Di Bursa Efek Indonesia Periode 2014-2018.

Tidak terdapat pengaruh rasio rentabilitas tidak terlalu berpengaruh signifikan terhadap Return Saham dikarenakan nilai perbandingan laba sekarang dengan jumlah modal perusahaan tidak sebanding, dimana pada variabel ROE pada perusahaan LQ45 yang terdaftar di Bursa Efek Indonesia Periode 2014-2018 memiliki nilai mean sebesar 0,2262 dan median 0,1200 dengan standar deviasi sebesar 0,38661. Batas minimum adalah 0,00 dengan maksimum 1,37.

Hasil yang telah dilakukan dalam penelitian ini telah didukung oleh beerapa penelitian salah satunya yang telah dilakukan oleh Okta (2014) hasil dari penelitian tersebut kemudian ditemukan sehingga tidak dapat ditemukan pula adanya pengaruh dari profitabilitas tersebut terhadap profitabilitas dari adanya return dari saham. Rasio dari rentabilitas / profitabilitas, telah memperlihatkan adanya kemampuan yang terdaat dari perusahaan dalam rangka mendapatkan sebuah keuntungan, rasio ini memakai yakni return on equity. Semakin tinggi bentuk dalam rasio inimaka juga ada kemungkinan akan semakin baik pula returm yang ada pada saham yang kemudian akan didapatkan atau diperoleh oleh investor, artinya semakin kuat posisi pemilik perusahaan maka demikian pula sebaliknya.

ROE ialah apakah perusahaan mampu mengukur untuk menghasilkan keuntungan dengan cara menggunakan modal sendiri. Tingkat ROE juga menunjukkan tingkat kemampuan perusahaan dalam menghasilkan laba bagi pemegang saham. Berdasarkan data penelitian diketahui bahwa perubahan ROE mengalami penurun dan kenaikan selama tahun penelitian, dilihat dari tren tingkat kenaikan lebih besar daripada tingkat penurunannya. Hal ini menunjukkan bahwa tingkat ROE semakin tinggi, sehingga perusahaan ketergantungan dalam mendanai biaya operasionalnya terhadap pihak eksternal (kreditur) yang semakin kecil. Oleh karena itu, perusahaan dalam pengalokasian laba untuk membayar hutang lebih kecil daripada yang dibagikan kepada investor dalam bentuk deviden, sehingga investor lebih tertarik pada perusahaan tersebut.

\section{Pengaruh Rasio Likuiditas, Rasio Solvabilitas dan Rasio Rentabilitas secara Bersama- sama terhadap Return Saham}

Hasil penelitian ditemukan nilai $\mathrm{F}$ hitung 5.037 dengan nilai signifikansi sebesar 0,005 ( $>0,05)$. Hal ini berarti bahwa secara bersama-sama rasio likuiditas, rasio solvabilitas dan rasio rentabilitas berpengaruh signifikan terhadap Return Saham Pada Perusahaan LQ45 yang Terdaftar di Bursa Efek Indonesia Periode 2014-2018.

Hasil penelitian ini didukung oleh penelitian yang dilakukan oleh Ulul Nur Azizah (2018) ditemukan secara bersama-sama rasio likuiditas, rasio solvabilitas dan rasio rentabilitas berpengaruh signifikan terhadap Return Saham. Return saham yaitu salah satu faktor yang mendorong para investor berinvestasi dan imbalan atas keberanian investor menanggung resiko atas investasi yang dilakukannya. Return saham diartikan sebagai penghasilan yangdiperoleh dari sejumlah dana diperoleh selama periode investasi yang diinvestasikan dalam bentuk saham (Firdaus, 2015: 37). return sesungguhnya (realized return) dan return yang diharapkan atau 
return ekspektasi merpakan bagian dari return saham. Return sesungguhnya yaitu return yang sudah terjadi, yang dihitung dariselisih harga sekarang relatif terhadap harga sebelumnya, Sedangkan return ekspektasi adalah return yang diharapkan akan diperoleh oleh investor di masa yang akan datang (Pohan, $2015: 44)$.

\section{KESIMPULAN DAN SARAN \\ Kesimpulan}

1. Rasio Likuiditas tidak berpengaruh terhadap Return Saham Pada Perusahaan LQ45 yang Terdaftar di Bursa Efek Indonesia Periode 2014-2018, karena $t$ hitung $<\mathrm{t}$ tabel dan signifikansi $(0,213>0,05)$.

2. Rasio Solvabilitas tidak berpengaruh terhadap Return Saham Pada Perusahaan LQ45 yang Terdaftar di Bursa Efek Indonesia Periode 2014-2018, karena nilai t hitung < $\mathrm{t}$ tabel dan signifikansi $(0,084>0,05)$,

3. Rasio Rentabilitas tidak berpengaruh terhadap Return Saham Pada Perusahaan LQ45 6ang Terdaftar di Bursa Efek Indonesia Periode 2014-2018, karena nilai t hitung < t tabel dan signifikansi $(0,108>0,05)$.

4. Secara bersama-sama Rasio Likuiditas, Rasio Solvabilitas dan Rasio Rentabilitas berpengaruh signifikan terhadap Return SahamPada Perusahaan LQ45 yang Terdaftar diBursa Efek Indonesia Periode 2014-2018, karena nilai F hitung 1.519 dengan nilai signifikansi sebesar $0,005(\mathrm{p}>0,05)$.

\section{Saran}

1. Pada penelitian ini terlihat semua rasio tidak memberikan pengaruh yang signifikan terhadap Return Saham Pada Perusahaan LQ45 yang Terdaftar di Bursa Efek Indonesia Periode 20142018, maka dari itu sebaiknya melihat variabel lain yang memberikan kontribusi signifikan tehadap return saham seperti rasio-rasio lain yang belum digunakan dalam penelitian ini.

2. Untuk menambah bahan penelitian pada Universitas Negeri Padang dan sebagai referensi atau ilmu tambahan bagi mahasiswa yang sedang mengerjakan penelitian.

\section{DAFTAR PUSTAKA}

Agussalim Manguluang. (2016). Metodologi Penelitian, Ekasakti Press, Padang.

Asnawi dan Wijaya. (2015). Pasar Modal (Acuan Teoritis dan Praktis Investasi di Instrumen Pasar Modal) . Yogyakarta: Graha Ilmu.

Bambang Wahyudiono. (2014). Mudah Membaca Laporan Keuangan. Raih Asa Sukses, Perum Bukit Permai. Jakarta.

Burhan Bungin. (2014). Metodologi penelitian kuantitatif, komunikasi, ekonomi, dan kebijkan public serta ilmu ilmu sosial. Kencana prenada media group. Jakarta.

Darsono. (2011). Pedoman Praktis Memahami Laporan Keuangan, Edisi pertama. Andi : Yogyakarta

Halim. (2015). Analisis Investasi. Edisi Dua. Jakarta: Salemba Empat.

Habib. (2012). Kiat Jitu Peramalan Saham. Jakarta: Gramedia Pustaka Utama.

Harahap. (2010). Analisis laporan keuangan. Nuga Medika. Yogyakarta,

Hartono, Jogiyanto. (2011). Teori Portofolio dan Analisis Investasi. Edisi Ketujuh, BPFE Yogakarta. 
Helfert, Erich A. (2014). Teknik Analisis Keuangan, Terjemahan Edisi Kedelapan. Jakarta: Erlangga.

Idris. (2014). Analisis Data Kuantitatif. UNP Padang.

Jumingan. (2014). Analisis Laporan Keuangan. Cetakan Pertama, PT. Bumi Aksara, Jakarta.

Kasmir. (2012). Manajemen Perbankan. Edisi Revisi 9. Jakarta Rajawali pers.

Keown, Martin, Petty, Scott. (2013). Manajemen Keuangan. Prinsip-prinsip dan Aplikasinya. Edisi kesembilan, jilid 1, PT INDEKS kelompok GRAMEDIA.

Martono, Agus Harjito. (2011). Manajemen Keuangan. Edisi Pertama Cetakan Kelima, EKONISIA, Yogyakarta.

M. Hanafi. (2010). Analisa Laporan Keuangan. Bandung.

Munawir. (2010). Analisis Laporan Keuangan.Cetakan Kelima, Liberty, Yogyakarta.

Nanang Martono. (2014). Metodologi penelitian kuantitatif, Edisi revisi II, PT RajaGrafindo Persada, Jakarta.

Prawira. (2016). Manajemen Keuangan Teori dan Aplikasi.Yogyakarta:BPFE

Pohan. (2015). Manajemen Keuangna Lanjutan. PT. Gramedia. Jakarta.

Samsul. (2013). Manajemen Keuangan Modern. Bumi Aksara, Jakarta.

Sekaran Uma. (2010). Research Methods For Business, Salemba Empat, Jakarta.

Wahyono, Ono. (2014). Pengaruh Kinerja Keuangan terhadap Harga Saham pada Perushaan Manufaktur Subsektor barang Konsumsi yang Terdaftar di Bursa Efek Indonesia 20072011.

Ade Afinanda. (2015). Analisis Pengaruh Rasio keuangan Terhadap Return Saham Perusahaan Dalam indeks LQ 45Tahun 2010 -2013

Desliana. (2017). Analisis pengaruh rasio Keuangan terhadap return Saham pada perusahaan non bank LQ 45.

Rusadi dan Hermanto (2017). Pengaruh Profitabilitas, Likuiditas, Leverage, Aktivitas Dan Nilai Pasar Terhadap Return Saham.

Rusydina dan Praptoyo (2017). Pengaruh Rasio Keuangan Terhadap Return Saham.

Septiana dan Wahyuati (2016).Pengaruh Rasio Keuangan Terhadapreturn Saham Pada Perusahaan Manufaktur.

Silvia. (2015). Pengaruh Rasio Keuangan Terhadap Return Saham Perusahaan Manufaktur Di

Bursa Efek Indonesia (Studi kasus Pada Perusahaan Manufaktur Sektor Food And Beverage).

Indah. (2016). Pengaruh Rasio Keuangan Terhadap Return Saham Perusahaan Manufaktur Di Bursa Efek Indonesia (Studi kasus Pada Perusahaan Manufaktur Sektor Food And Beverage).

Novia. (2015). Analisis pengaruh rasio keuangan terhadap Return saham pada indeks LQ-45 Di Bursa Efek Indonesia.

Novalia. (2015). Analisis Pengaruh Rasio Keuangan Terhadap Return Saham Pada Perusahaan Otomotif Yang Terdaftar Di Bursa Efek Indonesia Pada Tahun 2009-2013. 